\title{
ОСОБЕННОСТИ ОБРАЗА ВРАГА В ДЕТСКИХ ВОСПОМИНАНИЯХ (НА ПРИМЕРЕ ВЕЛИКОЙ ОТЕЧЕСТВЕННОЙ ВОЙНЫ)
}

\section{FEATURES OF THE IMAGE OF THE ENEMY IN CHILDHOOD MEMORIES (ON THE EXAMPLE OF THE GREAT PATRIOTIC WAR)}

A. Veterkov

Summary: The article is devoted to the study of the features of the image of the enemy in the minds of Soviet children during the Great Patriotic War and in the early post-war years. Children's memories are a slightly different type of historical sources, due to the age of the subject of the memories, they are different from the memoirs of adults and eyewitnesses of the events.

The aim of the research is to study the features of the image of the enemy in childhood memories (using the example of the Great Patriotic War).

The material of the study was the recollections of children during the Great Patriotic War.

The research methods were: scientific literature analysis on the research topic, analysis, synthesis, generalization.

In the course of the study, it was found that the image of the enemy in childhood memories is distinguished by subjectivity and specific perception of the surrounding reality, characterized by personal perceptions, an emotional component - contradictory perception, transitional perception from an enemy with a weapon in his hands to a pitiful captive enemy.

Keywords: The Great Patriotic War, children, memories, enemy, occupiers, prisoners of war.
Ветерков Александр Иванович

К.и.н., дочент, Российская открытая академия транспорта Российского университета транспорта (РОАТ (РУТ) (МИИТ) (2. Москва) aveterkov@yandex.ru

Аннотация: (татья посвящена изучению особенностей образа врага в сознании советских детей в годы Великой Отечественной войны и в первые послевоенные годы. Детские воспоминания являют собой несколько иной тип исторических источников, В силу возраста субъекта воспоминаний отличны от мемуаров взрослых и уже состоявшихся очевидцев событий.

Целью исследования является изучение особенностей образа врага в детских воспоминаниях (на примере Великой Отечественной войны).

Материалом исследования послужили воспоминания детей времен Великой Отечественной войны.

Методами исследования являлись: анализ научной литературы по теме исследования, анализ, синтез, обобщение.

В ходе исследования установлено, что образ врага в детских воспоминаниях отличается субъективностью и специфическим восприятием окружающей действительности, характеризуется личностными восприятиями, эмоциональной составляющей, - противоречивостью восприятия, переходностью восприятия от врага с оружием в руках к жалкому пленному врагу.

Ключевые слова: Великая Отечественная война, дети, воспоминания, враг, оккупанты, военнопленные.

\section{Ввецение}

$\mathrm{B}$ имание историков все больше привлекает изучение образа врага в детских воспоминаниях Великой Отечественной войны. Необходимо выделить целый ряд исследований, посвященных данной теме.

Исследование проблематики формирования и фиксации образа врага в сознании советских детей в годы Великой Отечественной войны и в первые послевоенные годы представляет собой сравнительно новое направление для специалистов в области отечественной истории. Данная проблематика пока еще не становилась предметом фундаментального изучения ученымиисториками, однако следует отметить, что в последние десятилетия проблема формирования «образа врага» разрабатывается весьма активно в социальных и исторических исследованиях.
В частности, следует отметить работы И.Б. Гасанова [6], Е.С. Сенявской [15], М.М. Амирхановой, Л.Г. Каймаразовой, Ю.М. Лысенко[7] и др. Также данная проблематика интересует и зарубежных ученых [18]. Тем не менее, особенности образа врага в детском и подростковом восприятии требуют более глубокого и детального специализированного исследования.

Первые публикации, рассказывающие о детях военного времени, появились непосредственно в годы Великой Отечественной войны и в большинстве своем представляли газетные и журнальные заметки, очерки и статьи. Во многих из них рассказывалось о героизме детей и подростков на фронте и в тылу в годы Великой Отечественной войны. Многие из них послужили основой для современных изданий [13].

Е.Ф. Кринко, исследуя первые публикации по данной 
теме, отмечает, что к их особенностям можно отнести информирование читателей об активном участии несовершеннолетних граждан СССР в борьбе с врагом в качестве разведчиков, партизан, связных, акцентировалось внимание на патриотических чувствах к Родине. Тем не менее автор делает вывод о том, что военное детство как комплексная научная проблема в полной мере ещё недостаточно проанализирована с точки зрения исторической науки [10,с.25].

По мнению М.А. Рыбловой к середине 1960-х гг. в СССР уже сформировался образ героя - ребенка и подростка, чьи подвиги использовали в рассказах, поучительных примерах нравственности и патриотизма. Как правило, герои наделялись деталями биографии, членством в пионерской или комсомольской организации [3,c.8]. Примерами могут служить подвиги молодогвардейцев и пионеров-героев.

Исследования А.В. Архиповой, Е.Ф. Кринко, И.И. Куриллы, М.А. Рыбловой, Т.П. Хлыниной посвящены воспоминаниям детей и подростков о битве и жизни жителей города в военном Сталинграде $[2,3,11]$. Образ врага через призму детского рисунка исследовали С.А. Аргасцева [1] и В.Е. Ловягина [12]. М.П. Назарова изучала особенности образа врага, формировавшегося в детских играх [14]. Л.А. Фалалеева рассматривала феномен восприятия детьми военнопленных вражеских армий [16].

В публикациях Е.Ф. Кринко представлены исследования историографии Великой отечественной войны в памяти детей [10].

Г.Ш. Каймаразов, Л.Г. Каймаразова, Л.М. Алибекова исследовали образ врага с точки зрения истории, философии и психологии [9].

В историографии и художественной литературе присутствует большое количество материалов, посвященных подвигам, однако повседневные воспоминания детей эпохи войны изучены в гораздо меньшей мере. Хотя в последнее время появляются публикации источников, включающих дневники подростков, воспоминания и транскрипции интервью.

Советский Союз вел целенаправленную агитационную политику, направленную на формирование вражеского образа, как и все страны-участницы Второй Мировой войны. Война была жесточайшим столкновением держав, поэтому требовала от руководителей воюющих сторон привлечения ресурсов, которые напрямую не относились к ведению боевых действий.

Война поневоле вовлекла детей в водоворот ужас- ных событий, и их воспоминания наполнены яркими эмоциональными характеристиками, которые нельзя проследить в мемуарах взрослых очевидцев событий. На основании изученного фактологического материала целесообразно утверждать, что детское восприятие образа врага отличалось от миропонимания взрослых людей в рассматриваемую эпоху.

В историографии выделяются несколько основных видов источников, в которых зафиксированы представления современников о неприятеле, причем освещение в каждом из них «образа врага» заметно различается. При рассмотрении основных аспектов данной проблематики особый интерес представляют источники личного происхождения - письма, дневники, воспоминания. Последние, как источники личного происхождения, могут сыграть существенную роль в изучении истории повседневности, образа жизни, социальной психологии, мировоззрения детей военных лет - современников событий Великой Отечественной войны.

В сознании советских детей сложилось два образа врага: «один - глобальный, сформировавшийся под воздействием официальной пропаганды, второй - бытовой, который возникал при непосредственных контактах с представителями вражеской стороны: на оккупированной территории (кому пришлось с этим столкнуться), с военнопленными» [9,с.69]. Е.С. Сенявская считает, что на изменение образа врага влияли продолжительность войны, ход и характер боевых действий, победы и поражения, настроения на фронте и в тылу, причем более «мобильным» был именно второй, «бытовой», образ. Что же касается первого образа, «глобального», то «он закрепляется в сознании нескольких поколений, приобретая характер «послевоенного синдрома» [15, с.72].

В большей степени следует обратить внимание на формирование «бытового» образа офицеров и солдат вражеской (главным образом германской) армии. При этом целесообразно учесть, что представления у большинства советских детей о враге складывались в основном из вторичных источников информации (сообщения в СМИ, письма с фронта, рассказы вернувшихся с войны родственников и т.д.). У советских детей сформировались официально-пропагандистский, личностно-бытовой и ретроспективный типы образа. В такой же последовательности шел переход от одного типа к другому на протяжении военного и послевоенного времени.

\section{Материалы и методы исследования}

Целью исследования является изучение особенностей образа врага в детских воспоминаниях (на примере Великой Отечественной войны). 
Материалом исследования послужили воспоминания детей времен Великой Отечественной войны.

Методами исследования являлись: анализ научной литературы по теме исследования, анализ, синтез, обобщение.

\section{Результаты исследования}

В воспоминаниях детей военного времени типичный образ врага носит яркую эмоциональную окраску. С одной стороны, немецкий военнослужащий соотносится с некой враждебной силой, способной уничтожить жизни как самих детей, так и их близких - родителей, дальних родственников, друзей, ровесников, соседей. Подобная враждебная сила была способна внушить ужас в детское сознание. С другой стороны, можно наблюдать и нотки любопытства, доброжелательности и сострадания (особенно в те моменты, когда речь шла об общении юных очевидцев событий войны с военнопленными).

Страшное слово «война» накладывало свой отпечаток на сознание детей. Начало войны предвещало нечто новое, страшное и неизбежное. Первый день войны отложился в смутных и нечетких воспоминаниях совсем еще маленьких детей. Вот что вспоминала Л.Н. Сулимова (Быстрова), 1938 г.р.: «22 июня 1941 г. мне не было и трех лет, но день этот прочно до сих пор поселился в памяти. Помню его с момента выступления по радио Молотова, помню лица моих близких, которые его молча слушали. Я мало что поняла в самой речи, но главное осознала (теперь я так могу назвать то мое состояние) - происходит что-то важное для моих родителей и бабушки... Вскоре принесли «бумажку», и мама с папой засуетились, а бабушка сказала, что это повестка для папы и он уходит на войну. Я решила, что во всем виновата эта «бумажка» и спрятала ее в песочнице. Когда папа совсем собрался и уже уходил, он стал искать злосчастную повестку, но я молчала, и если бы не хитрая бабушка, уговорившая меня вернуть потерю, то папе пришлось бы понервничать»[4, с.79].

Страх перед вооруженным врагом больше всего проявлялся у маленьких детей. По воспоминаниям Н.А. Захаровой 1937 г.р., «мама тихонько перешагивала через спящих на полу немцев. Она пробиралась к нам ночью... Немцев мы очень боялись... Они были огромными» [17, л.58]. Маленькая девочка описывает этот эпизод, ориентируясь главным образом на воспоминания матери. Сами же воспоминания ребенка крайне смутные - мы отмечаем страх перед фашистами как перед некими огромными чудовищами, которые без приглашения пришли в твой дом и без разрешения в нем поселились. Вот что вспоминает другой очевидец событий Л.Н. Сулимова (Быстрова), 1938 г.р.: «сейчас вот задумалась, как же рано тогда взрослели дети, если я, трехлетняя малышка, очень четко помню разговоры взрослых в то тревожное время. Однажды мама с тетей укрывали окна и разговаривали между собой, не заметив, что я рядом. Тетя говорит: «Жалко Ляльку (это про меня) и маму (это мою бабушку), если немцы придут, то нас с тобой (это она маме) угонят в Германию работать, а они не нужны и умрут от голода». Вот тут мне стало страшно, и с этим чувством я жила до тех пор, пока немцев не отогнали от Москвы»[4,с.81]. «Тревога взрослых передавалась и нам» [13, кн.2, с.182] - вспоминал Алексей Воднев о первых днях войны. Враг был неведом, и неизвестность ещё больше пугала детей.

В данных эпизодах следует обратить внимание на бессознательное ожидание угрозы или опасности, нежели осознанное восприятие того, что перед тобой враги, напавшие на твою Родину. Как отмечает К. Изард «у маленьких детей, также как и у животных, ощущение угрозы или опасности сопряжено с физическим дискомфортом, с неблагополучием физического «Я»; страх, которым они реагируют на угрозу, это боязнь физического повреждения» [8, с.293].

Отношение к врагу становится более осознанным у детей, достигших школьного возраста. Вот что вспоминает В.В. Морозов, 1934 г.р.: «немцы заняли деревню зимой 1942 г. Они давали нам хлеб и относились к детям со снисхождением. Но были и злые... Случилась трагедия. В деревню привели пленных партизан, всех жителей согнали. Пленных заперли в сарай, облили бензином и подожгли. Сказали, что так будет с каждым, кому не нравится новая власть» $[17$, л.25]. По воспоминаниям Л.А. Бочковой: «Я хоть и восьмилетняя, но все слышу, как взрослые общаются: вот там повесили и девчат, и ребят» [5, с.243]. Подобные картины зверского отношения к людям (пускай даже к террористам с точки зрения фашистов), наносили глубочайшие психологические травмы, которые оставались в сознании уже повзрослевших детей войны на протяжении долгих послевоенных десятилетий.

В детской памяти также сохранились эпизоды относительно гуманного отношения врага к жителям оккупированных территорий. Милосердие и сострадание, которое проявляли военнослужащие вражеской армии, также нашли свое отражение в детских воспоминаниях. Детское восприятие действительности человека не разграничивает дружеское и враждебное отношение - нередко враг воспринимался как положительный герой, в связи с этим воспоминания о конкретных людях не имеют негативной окраски. Родители С.Ю. Морозовой 1930 г.р. пострадали от сталинских репрессий, и воспитывала ее родная тетя. Вот что она вспоминает: «Краснодар был 
оккупирован немцами. Тетя заболела и.... я осталась совсем одна. Соседи подсказали, что в городе есть детский дом. Я своей рукой написала письмо немецкому бургомистру, и меня приняли в этот дом... Я не знаю, кто и на какие деньги нас содержал, но кормили три раза в день. Из костей и сои варили суп, давали по маленькому кусочку хлеба, который мы прятали в карманах на потом» [4, c.30].

«Как-то нас троих детей кто-то закрыл на замок. Окна были зарешеченные, с большими подоконниками. Мы, усевшись на подоконнике, наблюдали, как во дворе школы суетились румынские солдаты. В углу школьного двора стояла их кухня. Несколько раз старый солдаткашевар проходил мимо окна и видел голодных детей. Проходя в очередной раз, он с оглядкой, чтоб никто не увидел, швырнул в форточку бумажный сверток. Это была горячая каша»- вспоминает Ж. Г. Рамалданова (Куценко) [9, с. 71]. В воспоминаниях детей военных лет подобное отношение со стороны вражеских военнослужащих или поваров было нередкостью, однако еда из себя представляла в основном объедки или кости [13, кн.2, с. 270]

Л.С. Григорьянц на начало войны жила в Харькове, который дважды захватывали фашисты. Она вспоминает: «К нам на квартиру на постой определили 4-х немецких солдат, точнее, трое из них были немцы, а один - австриец. Этот австриец запомнился мне лучше всего. Когда он оставался один, то часто причитал: «Зачем эта война? Мне она не нужна. У меня дома хозяйство, дети. Зачем она мне?». Австриец часто, тайком, пока не видят другие солдаты, помогал нам, делился своим пайком» $[9$, c.71].

После Победы в мае 1945 г. отношение к поверженному врагу стало меняться. Касалось это изменение отношения не только взрослых, но и детей. Вот что вспоминает Т.Н. Спиридонова, 1939 г.р.: «запомнились мне пленные немцы, жившие в нашем дворе; их водили на различные строительные работы...Помню разные движущиеся игрушки, которые они мастерили из дерева и подручных материалов и обменивали на какую-нибудь еду»[4, с.66]. Л.Г. Удачина (Голубева), 1938 г.р., вспоминала следующее: «после войны квартал отстраивали пленные немцы. Мы, дети, были с ними в неплохих, «взаимовыгодных» отношениях: носили им маленькие пучки зелени с огорода, а они свободно пускали нас на стройку за чистым влажным песком для «куличиков». Они о чемто говорили на ломаном русском языке, смеялись, и, как мне представляется, всегда были нам рады»[4, с.77].

На основе приведенных фактов целесообразно сделать вывод о том, что формирование вражеского образа отличалось многофакторностью. Воспоминания детей отличаются чрезмерной яркостью и эмоциональной окрашенностью.

Первое впечатление о неприятеле характеризуются личностными восприятиями, эмоциональной составляющей. Во многом та или иная эмоция зависела от того, что само отношение военнослужащих неприятельской армии к населению оккупированных территорий Советского Союза было неоднозначным. Восприятие зависело от конкретных условий и ситуаций, в которых происходил межличностный контакт между детьми и солдатами враждебного государства. Не всегда военнослужащий неприятельской армии воспринимался как враг. В случае близкого доброжелательного контакта он выглядел не демоном и злодеем, а зачем-то пришедшем на твою землю иностранцем с оружием в руках.

Источники личного характера крайне важны для понимания сути той или иной исторической эпохи. Однако не всегда можно оценивать детские воспоминания как абсолютную истину. Особенности детской психологии откладывают специфический оттенок на восприятие окружающей действительности, что неминуемо приводит к искажению информации. Влияние страшных событий войны, связанных с катаклизмами, гибелью родственников, близких, разрушением знакомого и родного мира, повлияли на формирование образа врага. Но несмотря на все вышеназванные обстоятельства воспоминания детей войны способны окунуть исследователя в эпоху страшного горя, и какими бы субъективными они не были, их отличает способность помочь нам взглянуть на эпоху глазами наиболее беспристрастных очевидцев случившегося - маленьких детей. Помимо жестокости, превосходства и насилия, дети видели участие, сострадание и сожаление. Нередко сами военнослужащие неприятельской армии отождествляли себя не с солдатами, а с отцами, у которых также остались свои дети.

Послевоенные воспоминания позволяют сделать вывод о том, что в послевоенные годы ненависть к пленным сменилась даже не неприязнью, а любопытством и снисходительным состраданием. Своего рода это была милость окровавленного и обессиленного победителя к поверженному в жесточайшей схватке врагу. Ожесточенные боевые действия ушли в историю, что стало главным мотивом в изменении отношения. Враг с оружием в руках, готовый убить близких и родных людей, наиболее значимых для ребенка, сменился жалким пленным врагом.

Так, детские воспоминания очевидцев событий военных лет обладают оригинальностью и помогают реконструировать события прошлого, многие из которых не 
нашли своего места в других исторических источниках.

\section{ЗакАючение}

Таким образом, на основе вышеизложенного целесообразно сделать следующие выводы.

Образ врага в детских воспоминаниях:

- отличается субъективностью и специфическим восприятием окружающей действительности, в связи с этим может быть искажен;

- характеризуется личностными восприятиями, эмоциональной составляющей;
- противоречивостью восприятия: с одной стороны, ярким детским воспоминанием являлось ожидание угрозы или опасности, которая готова убить ребенка и его близких, нежели осознанное восприятие того, что перед тобой враги, напавшие на твою Родину; с другой стороны, можно было увидеть и ощутить на себе гуманное отношение врага к жителям оккупированных территорий, при этом неприятель не ассоциировался с «врагом», а воспринимался как положительный герой, готовый помочь;

- переходностью восприятия от врага с оружием в руках к жалкому пленному врагу.

\section{ЛИТЕРАТУРА}

1. Аргасцева С.А. Коллекция рисунков Сталинградских детей // Дети и война: социально-психологические, демографические, историко-культурные последствия войны для детей и юношества. Материалы Всероссийской научно-практической конференции, г. Волгоград, 23-25 октября 2014 г. Волгоград: Альфа, 2015. С. 4-6.

2. Архипова Е.В., Кринко Е.Ф., Рыблова М.А., Хлынина Т.П., Дети Сталинграда рассказывают о себе: особенности и проблемы записи воспоминаний очевидцев // Русский архив. 2015. № 4. С. 256-266.

3. Воспоминания жителей города / Под редакцией М.А. Рыбловой. Волгоград: Изд-во Волгоградского филиала РАНХИГС, 2015. 390 с.

4. Вспомнить все: эстафета памяти: альманах / Т.Н. Спиридонова. Ярославль, 2014.84 с.

5. Детство и война: культура повседневности, механизмы адаптации и практики выживания детей в условиях Великой Отечественной войны (на материалах (талинградской битвы) / под ред. М.А. Рыбловой. Волгоград: Издательство Волгоградского филиала ФГБОУ ВО РАНХиГС, 2015. 336 с.

6. Гасанов И.Б.Национальные стереотипы и «образ врага». М.: РАУ, 1994. 40 с.

7. Детство, опаленное войной. Дагестан. 1941-1945 гг. Воспоминания / сост. М.М. Амирханова, Л.Г. Каймаразова, Ю.М. Лысенко. Махачкала, 2015.464 с.

8. Изард К. Психология эмоций. СПб.: Литера, 2009. 464 с.

9. Каймаразов Г.Ш., Каймаразова Л.Г., Алибекова Л.М. Трансформация «образа врага» в сознании дагестанских детей в конце 1930-х - 1950-е гг. // Исторические, философские, политические и юридические науки, культурология и искусствоведение. Вопросы теории и практики. Тамбов, 2016. С.68-73.

10. Кринко Е.Ф. Детство военных лет (1941-1945 гг.): проблемы и перспективы изучения // Вестник Адыгейского государственного университета. 2006. C. $25-31$.

11. Кринко Е.Ф., Курилла И.И., Рыблова М.А., Хлынина Т.П. Детство Великой Отечественной: историография, память, проблемы поля // Дети и война: Сталинградская битва и жизнь в военном Сталинграде в воспоминаниях жителей города. Волгоград: Изд-во РАНХИГС, 2014. 215 с.

12. Ловягина В.Е. Рисунки детей блокадного Ленинграда. Из собрания Государственного музея истории Санкт-Петербурга // Дети и война: социально-психологические, демографические, историко-культурные последствия войны для детей и юношества. Материалы Всероссийской научно-практической конференции, г. Волгоград, 23-25 октября 2014 г. Волгоград: Альфа, 2015. С. 93-102.

13. Маленькие герои большой войны. В 3-х кн. / Под. ред. А.В. Никонорова. М.: ЛитРес, 2015,2016.

14. Назарова М.П. Игры военного детства: новые формы и функции // Дети и война: социально-психологические, демографические, историко-культурные последствия войны для детей и юношества. Материалы Всероссийской научно-практической конференции, г. Волгоград, 23-25 октября 2014 г. Волгоград: Альфа, 2015. С. 100-134.

15. Сенявская Е.С. Противники России в войнах XX века (Эволюция «образа врага» в сознании армии и общества). М.: Российская политическая энциклопедия (РОССПЭН),2006. 288 c.

16. Фалалеева Л.А. «0ни не виноваты, их послали, а если бы не пошли, их бы расстреляли». Образы военнопленных в воспоминаниях детей военного Сталинграда // Дети и война: социально-психологические, демографические, историко-культурные последствия войны для детей и юношества. Материалы Всероссийской научно-практической конференции, г. Волгоград, 23-25 октября 2014 г. Волгоград: Альфа, 2015. С. 214-220.

17. Центр документации новейшей истории Государственного архива Ярославской области (ЦДНИ ГАЯО). Ф.212. Оп.1. Д.26.

18. Stein J.G. "Image, Identity and Conflict Resolution" // Managing Global Chaos: Sources of and Responses to International Conflict / edited by A. Chester, F.0. Hampson et all. Washington, D.C. - United States Institute of Peace Press, 1996. Pp. 93-111. 